ISSN:2656-4270 (Online) 1410-4466 (Print) Accredited by Ministry of Research, Technology, and Higher Education with the ranking of Sinta (S4) SK NO.28/E/KPT/2019, 26th September 2019
Buletin Penelitian Sosial Ekonomi Pertanian Fakultas Pertanian Universitas Haluoleo

2020:22(1):1-6

http://ojs.uho.ac.id/index.php/sosek

doi: http://dx.doi.org/10.33772/sosek.v22i1.10879

\title{
THE ANALYSIS OF PRODUCTION AND INCOME OF MILKFISH CULTIVATION IN NORTH KONAWE DISTRICT
}

\author{
Muhammad Aswar Limi ${ }^{{ }^{*}}$ \\ ${ }^{1}$ Department of Agribusiness Faculty of Agriculture Halu Oleo University Kendari Indonesia 93232 \\ ${ }^{*}$ Corresponding author : aswar_agribusiness@yahoo.com
}

To cite this article:

Limi, M. (2020). The Analysis of Production and Income of Milkfish Cultivation in North Konawe District. Buletin Penelitian Sosial Ekonomi Pertanian Fakultas Pertanian Universitas Haluoleo, 22(1), 1 - 6. doi:http://dx.doi.org/10.33772/bpsosek.v22i1.10879

Received: February 03, 2020; Accepted: April 25, 2020; Published: April 27, 2020

\begin{abstract}
This study aimed to determine how much production and income earned by farmers in cultivating milkfish in North Konawe District. Research on the analysis of production and income of milkfish cultivation was carried out in Motui Sub-District, North Konawe District. The population was farmers who manage milkfish cultivation as many as 130 milkfish farming businesses so that the total sample was 56 milkfish farming businesses. The sample in this study was determined by simple random sampling. The data obtained were analyzed using the analysis of production, revenue, and income. The results of this research found that milkfish cultivation has an average production of $525 \mathrm{~kg} / \mathrm{ha}$ and an average income of IDR6,629,945 but has a higher RC ratio of 5.8 because farmers relied on natural food as the main source of milkfish so that production costs can be minimized. The production of milkfish farming can be increased by improving the cultivation system from traditional system to intensive system.
\end{abstract}

Keywords: cultivation; income; milkfish; North Konawe; production

\section{INTRODUCTION}

The development of the fisheries sub-sector, especially milkfish cultivation in fish farming, is being developed by community and government by utilizing the potential of resources in the coastal areas to increase the income of coastal communities in Indonesia. FitzGerald (2004) stated that milkfish is one of the most important types of aquaculture in Indonesia, as well as in several other Asian countries because milkfish is a species of fish that lives in warm water (Martinez et al., 2006). Milkfish is preferred in Asia-Pacific because it has soft meat and nutritional value (Chen, 2019).

Southeast Sulawesi is one of the regions in Indonesia that has the potential for the development of fish cultivation in ponds located in North Konawe District, especially in Motui SubDistrict where the production experienced an increase to 20,066kw in 2019 from 49.6kw in 2018 (BPS Kecamatan Motui, 2018; BPS Kecamatan Motui, 2019). One of the fish farming commodities in ponds that are cultivated by the community is milkfish. FitzGerald (2004); Martinez et al (2006) claimed that milkfish is a unique species from Canidae family that can tolerate broad environment (euryhaline). Milkfish has the ability to migrate to the estuary of the coast and is omnivorous animals whose growth is fast and resistant to disease so it is very good to be cultivated (FitzGerald, 2004).

Milkfish is one type of fish that is widely cultivated because it is a mainstay commodity of North Konawe District so that in 2018, the government provided milkfish seedlings, facilities and infrastructure for milkfish cultivation to overcome the high production costs (Darmawan et al., 2018). The main production factors of milkfish cultivation are mainly the cost of seeds, feed, medicines, and fertilizers which can affect the size of the production and income of fish farmers. The provision of milkfish seedlings assistance, as well as facilities and production targets that are used together with the production factors owned by farmers in the form of land and labor in the family, is expected to increase milkfish farmers' production so that the production facilities must be used as efficiently as possible to maximize the income obtained. Handayani et al (2019) said that the use of small costs will affect the profitability and income of milkfish farmers. Income has a close relationship with the 
production achieved because if production and prices increase, the income of milkfish pond farmers will tend to increase which will provide positive benefits for the welfare of coastal communities. Jaikumar et al (2013); Muslim (2019) stated that milkfish will be a good source of income for coastal fishermen and can improve the welfare of coastal communities. Based on this, the study aimed to find how much production and income earned by farmers in cultivating milkfish ponds in North Konawe District.

\section{MATERIALS AND METHODS}

This study of the analysis production and income of milkfish cultivation business was carried out in Motui Sub-district of North Konawe District so that the population in this study was the farmers who managed milkfish cultivation as many as 130 milkfish cultivation businesses so that the total sample was 56 milkfish cultivation businesses determined using the formula proposed by Slovin (Rianse \& Abdi, 2012). The sample in this study was determined by simple random sampling. The data obtained were analyzed using analysis of production, revenue, and income according to Soekartawi (1995) with the following equation:

Where:

$$
\mathrm{TR}=\mathrm{P} \times \mathrm{Q}
$$

$\begin{array}{ll}\text { TR } & \text { : Total revenue (IDR/season) } \\ \mathrm{P} & \text { : Price (IDR/season) } \\ \mathrm{Q} & \text { : Production(IDR/season) }\end{array}$

The calculation of milkfish farming income was done by calculating the difference between the revenue and costs of milkfish farming with the following equation:

Where:

$$
\mathrm{I}=\mathrm{TR}-\mathrm{TC}
$$

\section{RESULTS AND DISCUSSION}

\section{Characteristics of Respondents}

The characteristics of respondents is a description of the socio-economic conditions of respondents which also affect their ability to manage their business. Respondent characteristics described in the study included age, level of formal education, number of family dependents, and experience in managing a business.

\begin{tabular}{|c|c|c|c|}
\hline & Characteristics & Frequency & Percentage (\%) \\
\hline & Age (years old) & & \\
\hline & Productive $(15-54)$ & 54 & 96.43 \\
\hline & Non-productive (> 54) & 2 & 3.57 \\
\hline & Average & 37 & \\
\hline \multirow[t]{5}{*}{2.} & Education & & \\
\hline & Elementary school & 43 & 76.78 \\
\hline & Middle School & 12 & 21.42 \\
\hline & High school & 1 & 1.78 \\
\hline & Average & 6 & \\
\hline \multirow[t]{5}{*}{3.} & Farming Experience (Years) & & \\
\hline & Less Experienced $(<5)$ & 11 & 19.64 \\
\hline & Quite Experienced (5-10) & 15 & 26.78 \\
\hline & Experienced (> 10) & 30 & 53.57 \\
\hline & Average & 10 & \\
\hline \multirow[t]{4}{*}{4.} & Number of family dependents (person) & & \\
\hline & $2-4$ (small) & 26 & 46,42 \\
\hline & $>4$ (large) & 30 & 53,57 \\
\hline & Average & 4 & \\
\hline
\end{tabular}

Table 1. Characteristics of respondents

Source: Primary data processed, 2020 
Milkfish farmers who were at productive age will be considered capable of working to the maximum and producing milkfish. Table 1 shows that $96.43 \%$ of milkfish farmers were at the productive age with an average age of 37 years old. Farmers who are at productive age usually have good physical abilities, are more active in finding information that will lead to an increase in farmers' interest in using technology to increase the average productivity of their businesses and is an ideal age for work. Farmers of productive age have the ability to increase the work productivity and have a great ability to absorb information and innovative technology in the field of fisheries to the maximum, while farmers who have a relatively old age, despite having more work experience, but due to the physical conditions, the older the age, the more decrease the productivity. Annisa \& Lamusa (2014) stated that farmers who have a productive working age can still improve their farming. Furthermore, Noviyanti et al (2016) also stated that with the productive age of pond farmers will carry out management activities of the pond culture optimally.

Traditional farmers in Indonesia generally have low education but able to manage their business through personal experience and hereditary heritage from their parents. Table 1 shows the level of education and experience of milkfish farmers in which $76.78 \%$ of milkfish farmers have education at the elementary school level and as many as $53.57 \%$ have experience of milkfish cultivation businesses over 10 years. Low level of education will influence the farmers' knowledge in managing the milkfish cultivation business, but along with the increasing experience they have, it will improve their abilities and skills in managing the milkfish farming business. The higher the level of education, the more time is available for working and farmers who have higher education will tend to know the information and more freely in choosing appropriate technology and more selective in finding information that fits their business. Annisa \& Lamusa (2014) stated that the level of education will affect the farmers' ability and skills in terms of absorption of information related to their farming. The higher the education level of farmers, the broader the thought will be of new innovations. Highly educated farmers are more likely to accept, apply and even develop it compared to farmers with low education, but along with increasing farming experience, farmers who have primary school education will increase their skills in managing their farming so that it will be more efficient. lliyasu et al (2016); Athirah et al (2017) explained that the experience of farmers has a positive impact on the technical efficiency of fish farming. Furthermore, Annisa \& Lamusa (2014) added that the longer the farmer is engaged, the more it can affect the habits, skills, and expertise in conducting farming activities, which in turn will whether or not affect the production results.

The number of dependents is the number of family members who are dependent on milkfish farmer households. Table 1 shows that $53.57 \%$ of milkfish farmers are large families with family dependents of more than 4 people. lliyasu et al (2016); Athirah et al (2017) said that household size has a positive and significant impact on fish farming. The amount of family responsibility for milkfish farmers can give a negative and positive value to the family. The greater the dependency of milkfish farmers can affect the quality of life of the milkfish farmers family, especially the level of family economic welfare (income and expenditure) if the dependents are still in the non-productive age so it has not been able to help to increase family income but is still a source of family expenses so that the greater the responsibility of the family will further increase family expenses. Purwanto \& Taftazani (2018) added that the number of dependents will affect the level of family welfare if it is not balanced with sufficient income, so the number of dependents will continue to compare directly with the amount of income as a benchmark for the level of family welfare. The bigger family of milkfish farmers and referred to in the productive age will provide a positive value for milkfish farmers because it can help manage the milkfish farming business managed by the family. Annisa \& Lamusa (2014) stated that the number of family dependents also influence farming operations, the more the number of family dependents, the higher the interaction in the family, so that more farming thinkers.

\section{Production and Revenue of Milkfish Cultivation Business}

Production is an activity carried out to produce a product that has value so that it can provide benefits in the form of income received by business actors as the difference between revenue and production costs used. Every farmer will always strive so that his cultivation business can provide maximum results so that he has a high income to be able to meet the needs to improve family welfare. The average production, price, cost and income of milkfish cultivation in Motui Sub-district, North Konawe District can be seen in Table 2.

Milkfish is a product obtained from the results of production carried out by farmers through cultivation activities for six months of maintenance by using factors of production that have a significant effect on milkfish production (Riani, 2018). Table 2 shows the average production of traditional milkfish farming in the Motui District of $525 \mathrm{~kg} / \mathrm{ha}$. The products produced from this cultivation are included in a good category for traditional fishponds when compared to milkfish 
fishponds in Aceh Tamiang District. This is in accordance with the results of research by Indra \& Susilo (2017) stating that the production of milkfish in Aceh Tamiang District with non-intensive aquaculture business is $351.66 \mathrm{~kg} / \mathrm{ha}$. Furthermore, Ula \& Kusnadi (2017) added that traditional and semi-intensive cultivation technology provides a higher level of productivity.

Table 2. Average production, price, cost and income of milkfish farming

\begin{tabular}{clcc}
\hline No & & Variable & Amount \\
\hline 1. & Production (kg) & 525 \\
2. & Price (IDR) & 15,250 \\
3. & Revenue (IDR) & $7,998,660$ \\
4. & Cost (IDR) & $1,368,715$ \\
5. & Income (IDR) & $6,629,945$ \\
8 & R/C & 5.8 \\
\hline
\end{tabular}

Source: Primary data processed, 2020

The price of milkfish at the farmer's level during the study was on average of IDR15,250/kg, higher than the results of the previous study (Limi et al., 2020) where the price of milkfish on the coast of Kendari Bay was IDR.11,000/kg. The high price of milkfish in the research location is due to the research location which is around the nickel processing factory which is an investment company of the People's Republic of China, whose most workers are foreign workers from Chinese who live around the factory. For Chinese people, milkfish are included as a compulsory dish during Chinese New Year celebrations and a daily breakfast menu. A large amount of milkfish enthusiasts makes the price of milkfish in the market tend to be high because it is popular with the community related to the nutritional in addition to the milkfish meat is also quite delicious and can be used as a source of protein (Farmbos, 2020). The high selling price of milkfish has led to an increase in milkfish business revenue with an average of IDR7,998,660, according to Indra \& Susilo (2017) where the average acceptance of non-intensive milkfish farming in Aceh Tamiang District was IDR 7,033,272.84/ha whereas in Semarang City the average of milkfish cultivation was IDR 9,096,948 per season (Faiq et al., 2012).

The income of milkfish cultivation is the difference between the revenue obtained from the sale of milkfish and the costs used during the cultivation process. In Table 2, it can be seen that the average cost incurred by milkfish farmers was IDR 1,368,715 for land tax, milkfish seedlings, fertilizer to grow natural food (klekap), pesticides, labor costs and additional feed provided at the time of feed availability. Naturally in ponds has diminished. Production costs incurred by milkfish pond farmers are relatively smaller when compared to the average production cost of non-intensive milkfish cultivation in Aceh Tamiang District, IDR3,879,017.86 (Indra \& Susilo, 2017) and the average cost of milkfish farming in Semarang City was IDR6,231,245 per season (Faiq et al., 2012). The low cost of milkfish production in the study area is due to the fact that milkfish farmers in North Konawe District rely on natural food as a source of milkfish feed because additional feed is the largest cost component in milkfish cultivation as stated by Darmawan et al (2018) that milkfish cultivation requires costs production that is not small, especially in the procurement of fish feed that can affect the size of the income of milkfish farming. Furthermore, Handayani et al (2019) explained that the smaller the costs used, it will affect the income of milkfish farmers in ponds. The calculation of milkfish farming business income in the study location obtained an average of IDR 6,629,945/ha, the results are not much different from the average income of non-intensive milkfish farming in Aceh Tamiang District amounting to IDR4,338,971/ha (Indra \& Susilo, 2017). Based on the data of revenue and cost used, it is known that the $\mathrm{RC}$ ratio of milkfish farming was 5.8 where the value is higher than that of milkfish in Semarang City with an RC ratio of 1.62 (Faiq et al., 2012) and is still included in the feasible category to be developed because any costs incurred still bring in more revenue $(R / C>1)$. Ula \& Kusnadi (2017) traditional and semi-intensive cultivation technology is more profitable. Milkfish farmers can still increase their production and income to improve family welfare by improving the technology used from traditional system and semi-intensive system technology to intensive systems because according to Indra \& Susilo (2017), there is a very significant difference between the net income of milkfish farming non-intensive and intensive.

\section{CONCLUSIONS AND SUGGESTION}

Milkfish cultivation with a traditional system in Konawe District is the main source of income that supports the welfare of the milkfish farmers family, with an average production and income that is relatively similar to the traditional culture system in Indonesia with an average production of $525 \mathrm{~kg} / \mathrm{ha}$ 
and an average income of IDR $6,629,945$ but has a higher RC ratio of 5.8 because farmers rely on natural food as the main source of milkfish so that production costs can be minimized. The production of milkfish farming can be increased by improving the culture system from the traditional system to the intensive system

\section{REFERENCES}

Annisa, R., \& Lamusa, A. (2014). Feasibility Analysis Of Milkfish Farms In Dolago Village South Parigi Sub District Parigi Moutong District. Agrotekbis : E-Jurnal IImu Pertanian, 2(3), 337-342.

Athirah, A., Tarunamulia, Asaf, R., \& Mustafa, A. (2017). Financial Analysis of Various Methods of Mono and Poly Culture of the Milkfish and Shrimp (Case Study in Blanakan Sub-District, Subang Regency). Jurnal Sosial Ekonomi Kelautan Dan Perikanan, 12(2), 143-150.

BPS Kecamatan Motui. (2018). Kecamatan Motui Dalam Angka 2018. Badan Pusat Statistik Kecamatan Motui.

BPS Kecamatan Motui. (2019). Kecamatan Motui Dalam Angka 2019. Badan Pusat Statistik Kecamatan Motui.

Chen, N.-H. (2019). An Investigation on Taiwan milk fish. Journal of Chemical, Biological and Physical Sciences, 9(2), 165-172. https://doi.org/10.24214/jcbps.D.9.2.16572

Darmawan, D. I., Cholissodin, I., \& Dewi, C. (2018). Optimasi Formulasi Pakan pada Proses Budidaya Ikan Bandeng menggunakan Particle Swarm Optimization (PSO). Jurnal Pengembangan Teknologi Informasi Dan IImu Komputer (J-PTIIK) Universitas Brawijaya, 2(2), 776-784.

Faiq, H., Hastuti, D., \& Sasongko, L. A. (2012). Analisis Pendapatan Budidaya Bandeng Kelurahan Tugurejo Kecamatan Tugu Kota Semarang. MEDIAGRO: Jurnal IImu-IImu Pertanian, 8(1), 72-85. https://doi.org/http://dx.doi.org/10.31942/md.v8i1.1309

Farmbos. (2020). Ikan Bandeng. Farmbos.Com. https://farmbos.com/ikan-bandeng/\#z. Accessed: March, 2020

FitzGerald, W. J. (2004). Milkfish aquaculture in the Pacific: Potential for the tuna longline fishery bait market. (Issue April). Secretary of the Pacific Community, Aquaculture Section. Noumea, New Caledonia.

Handayani, R., Rejeki, S., \& Elfitasari, T. (2019). Evaluasi Kelayakan Usaha Budidaya Ikan Bandeng (Chanos chanos) Secara Semi Intensif di Kecamatan Ulujami Kabupaten Pemalang. Jurnal Sains Akuakultur Tropis, 3(1), 60-66.

lliyasu, A., Mohamed, Z. A., \& Terano, R. (2016). Comparative analysis of technical efficiency for different production culture systems and species of freshwater aquaculture in Peninsular Malaysia. Aquaculture Reports, 3, 51-57. https://doi.org/10.1016/j.aqrep.2015.12.001

Indra, S. balqies, \& Susilo, J. (2017). Perbedaan Pendapatan Usaha Budidaya Ikan Bandeng (Chanos chanos) Intensif dan Non Intensif di Kecamatan Manyak Payed Kabupaten Aceh Tamiang. Jurnal Penelitian Agrisamudra, 4(2), 57-66. https://doi.org/10.33059/jpas.v4i2.285

Jaikumar, M., Kumar, C. S., Robin, R. S., Karthikeyan, P., \& Nagarjuna, A. (2013). Milkfish Culture: Alternative Revenue for Mandapam Fisherfolk, Palk Bay ,. International Journal of Fisheries and Aquaculture Sciences., 3(1), 31-43.

Limi, M. A., Sara, L., La Ola, T., Yunus, L., Surni, Dirgantoro, M. A., Gafaruddin, A., Fyka, S. A., Batoa, H., \& Yusuf, E. A. A. (2020). Technical and economical analysis of milkfish farming on the coastal area of kendari bay after sedimentation. AACL Bioflux, 13(1), 403-413.

Martinez, F. S., Tseng, M., \& Yeh, S. (2006). Milkfish (Chanos chanos) Culture: Situations and Trends. 33(3), 229-244.

Muslim, T. (2019). Analisis Produktivitas Tambak Bandeng Dan Dampaknya Bagi Kesejahteraan Ekonomi Masyarakat Pesisir. Empower: Jurnal Pengembangan Masyarakat Islam, 4(1), 1-16. https://doi.org/10.24235/empower.v4i1.2567

Noviyanti, E., Rohmat, D., \& Nandi. (2016). Pengaruh usaha budidaya tambak terhadap kondisi sosial ekonomi petani tambak di Kecamatan Cibuaya Kabupaten Karawang. Antologi Pendidikan Geografi, 4(2), 1-14.

Purwanto, A., \& Taftazani, B. M. (2018). Pengaruh Jumlah Tanggungan Terhadap Tingkat Kesejahteraan Ekonomi Keluarga Pekerja K3L Universitas Padjadjaran. Focus: Jurnal Pekerjaan Sosial, 1(2), 33. https://doi.org/10.24198/focus.v1i2.18255

Riani. (2018). Analisis Efisiensi Alokatif Usaha Tani Tambak Ikan Bandeng (Chanos chanos F) di Kabupaten Aceh Utara. Agrifo: Jurnal Agribisnis Universitas Malikussaleh, 3(1), 69. https://doi.org/10.29103/ag.v3i1.678

Rianse, U., \& Abdi. (2012). Metodologi Penelitian Sosial dan Ekonomi (1st ed.). Alfa Beta.

Soekartawi. (1995). Analisis Usahatani. UI Press. 
Ula, M., \& Kusnadi, N. (2017). Analisis Usaha Budidaya Tambak Bandeng Pada Teknologi Tradisional Dan Semi_Intensif Di Kabupaten Karawang. Forum Agribisnis, 7(1), 49-66. https://doi.org/10.29244/fagb.7.1.49-66 